\title{
Hematological, morphological and morphometric characteristics of blood cells from rhea, Rhea Americana (Struthioniformes: Rheidae): a standard for Brazilian birds
}

\author{
S. S. M. Gallo ${ }^{a}$, N. B. Ederli ${ }^{b}$, M. O. Bôa-Morte ${ }^{a}$ and F. C. R. Oliveira ${ }^{a *}$ \\ aLaboratório de Sanidade Animal, Universidade Estadual do Norte Fluminense Darcy Ribeiro - UENF, \\ Av. Alberto Lamego, 2000, CEP 28013-600, Campos dos Goytacazes, RJ, Brazil

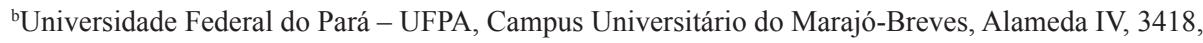 \\ CEP 68800-000, Marajó-Breves, PA, Brazil \\ *e-mail: foliveira@uenf.br
}

Received: March 12, 2014 - Accepted: June 3, 2014 - Distributed: November 30, 2015

(With 3 figures)

\begin{abstract}
Blood exams are an indispensable tool in bird medicine. This study aimed at describing values and aspects of rheas' hematology, Rhea americana, as well as analyzing the morphology and morphometry of all blood cells. Fifty eight adult rheas of both sexes from two farms, one in Cachoeiro de Itapemirim, Espírito Santo State and the other in São Carlos, São Paulo State, were selected. Blood samples were taken and RBC count, PCV and Hb levels measured and used in hematimetric indexes calculations. The total and differentiated leukocyte counts, as well as the TPP and fibrinogen were determined. Erythrocytes, leukocytes and thrombocytes were identified and characterized morphologically. The values for the red series and hematimetric indexes were: RBC $\left(2.81 \pm 0.15 \times 10^{6} / \mu \mathrm{L}\right), \mathrm{PCV}(44.20 \pm 2.86 \%), \mathrm{Hb}$ $(12.12 \pm 0.74 \mathrm{~g} / \mathrm{dL}), \mathrm{MCV}(15.75 \pm 0.89 \mathrm{fL}), \mathrm{MCH}(43.18 \pm 1.82 \mathrm{pg}), \mathrm{MCHC}(27.44 \pm 0.80 \mathrm{~g} / \mathrm{dL})$; the values of white series were: WBC $(12.072 \pm 4116 / \mu \mathrm{L})$, heterophils $(64.10 \pm 9.90 \%)$, eosinophils $(2.05 \pm 2.06 \%)$, monocytes $(6.40 \pm 2.99 \%)$, lymphocytes $(26.93 \pm 9.62 \%)$, basophils $(0.52 \pm 1.27 \%)$. One may conclude that on average, rheas' blood cells are larger than those of other birds, but these cells in smears cannot be differentiated only by their size. Besides rheas' leukocytes have different components and coloring as in other bird species, however, there are no components or staining aspects unique to the species.
\end{abstract}

Keywords: clinical pathology, hemogram, protein, ratites, Rhea americana.

\section{Características hematológicas, morfológicas e morfométricas de células sanguíneas de emas, Rhea americana (Struthioniformes: Rheidae): um padrão para aves brasileiras}

\section{Resumo}

Exames de sangue são uma ferramenta indispensável na medicina de aves. Este estudo teve como objetivo descrever valores e aspectos da hematologia de emas, Rhea americana, bem como analisar a morfologia e morfometria de todas as células sanguíneas. Cinquenta e oito emas adultas de ambos os sexos de dois criatórios, um em Cachoeiro do Itapemirim, ES e o outro em São Carlos, SP foram selecionadas. Amostras de sangue foram coletadas e CTH, Ht e níveis de $\mathrm{Hb}$ foram mensurados e usados para o cálculo dos índices hematimétricos. A contagem total e diferencial de leucócitos, assim como, PPT e fibrinogênio foram determinados. Eritrócitos, leucócitos e trombócitos foram identificados e caracterizados morfologicamente. Os valores para série vermelha e índices hematimétricos foram: CTH $\left(2,81 \pm 0,15 \times 10^{6} / \mu \mathrm{L}\right), \mathrm{Ht}(44,20 \pm 2,86 \%), \mathrm{Hb}(12,12 \pm 0,74 \mathrm{~g} / \mathrm{dL}), \mathrm{VCM}(15,75 \pm 0,89 \mathrm{fL}), \mathrm{HCM}(43,18 \pm 1,82 \mathrm{pg})$, CHCM $(27,44 \pm 0,80 \mathrm{~g} / \mathrm{dL})$; os valores da série branca foram: CTL $(12,072 \pm 4116 / \mu \mathrm{L})$, heterófilos $(64,10 \pm 9,90 \%)$, eosinófilos (2,05 $\pm 2,06 \%)$, monócitos $(6,40 \pm 2,99 \%)$, linfócitos $(26,93 \pm 9,62 \%)$, basófilos $(0,52 \pm 1,27 \%)$. Pode-se concluir que, na média, células sanguíneas de emas são maiores que as de outras aves, porém, não é possível diferenciar estas células em esfregaços somente pelo seu tamanho. Além disso, leucócitos de emas possuem diferentes componentes e coloração como acontece em outras espécies de aves, no entanto, não há nenhum componente ou aspectos tintoriais exclusivo para a espécie.

Palavras-chave: patologia clínica, hemograma, proteínas, ratitas, Rhea americana. 


\section{Introduction}

Rhea americana is a species of birds belonging to the ratite group, which includes ostriches (Struthio camelus), emus (Dromaius novaehollandiae), cassowaries (Casuarius casuarius) and kiwis (Apteryx spp.). Rhea americana is one of two rhea species, which also includes the lesser or Darwin rhea (Pterocnemia pennata) and both species are native to South America (Huchzermeyer, 2000). Ratite farming is considered an option to produce alternative livestock in Europe and North America. Commercial production of the greater rhea is a viable activity that generates meat, oil, leather, eggs, feathers, and liver protein extract (Giannoni, 1996).

Clinical signs in birds are very non-specific, and physical exams provide limited information. Blood exams are an indispensable tool in bird medicine (Lumeij, 1997). Comprehensive health assessments on wild bird populations, as hematology, can be used to assess the effects of many health related problems, such as contaminant intoxication, malnutrition, and exposure to infection (Sparling et al., 1999). With hematological exams, it is possible to qualitatively and quantitatively measure changes in the red and white blood cell fractions as well as changes in cell morphology that can assist in the diagnosis of several diseases and pathologies (Fudge, 1997).

Bird erythrocytes are large, nucleated and ovoid-shaped with a similarly shaped nucleus at the center. These cells have a deep purple color with uniformly clumped chromatin and a large, orange-pink cytoplasm, similar to mammals (Bounous and Stedman, 2000; Cardoso and Tessari, 2003). Their size ranges from 11 to $16 \mu \mathrm{m}$ long and 6 to $10 \mu \mathrm{m}$ wide. The Rheiformes have the largest cells of the bird class (Benez, 2001).

The leukocytes are responsible for the body's response to diseases or pathologies (Kokosharov, 1998). Heterophils are cells that measure about 5.1 to $11.4 \mu \mathrm{m}$ in diameter, the cytoplasm is clear and filled with cytoplasmic granules in rod-shape presenting a pastel eosinophilic tone. In general, the heterophil nucleus is polymorphonuclear, with one to five lobulations with dense chromatin. These cells are amoeboid and have motility (Lucas and Jamroz, 1961; Nirmalan et al., 1972; Campbell and Dein, 1984; Jain et al., 2000). The staining of the nucleus is basophilic with darker regions representing condensed chromatin (Lucas and Jamroz, 1961).

Eosinophils contain slightly basophilic cytoplasm, filled with spherical granules, of uniform size which have a live acidophilic tone. Mature eosinophils as well as heterophils are polymorphonuclear. These cells have dense chromatin, which in general displays markedly more intense staining than the nucleus of heterophils (Lucas and Jamroz, 1961; Hodges, 1977; Campbell, 1995). They are rounded and measure 4-11 $\mu \mathrm{m}$ in diameter (Campbell and Dein, 1984).

Monocytes have an average size of $12 \mu \mathrm{m}$ (Lucas and Jamroz, 1961). They are large with moderate amount of grayish blue cytoplasm, which occasionally contains small and discrete vacuoles; its nucleus is pleomorphic, with less condensed chromatin than in lymphocytes. These cells are round to oval in shape, with round nucleus and clear and cross-linked cytoplasm (Green and Blue-McLendon, 2000).

The typical lymphocyte is medium to relatively small in size, which is usually the smallest of the leukocytes. These cells are usually round with regular contours, where the nucleus is usually centralized and also round and regular shaped. The cytoplasm forms a narrow halo around the nucleus and has a hyaline or slightly granular texture colored in blue tones (Lucas and Jamroz, 1961; Hodges, 1977; Campbell, 1995). These are relatively small cells measuring 6 to $12 \mu \mathrm{m}$ in diameter (Coles et al., 1998).

The basophil contains cytoplasm filled with large and spherical granules which have under routine staining, basophilic tone of outstanding intensity. The cytosol usually does not stain or has a residual color slightly basophilic (Lucas and Jamroz, 1961; Campbell, 1995). The nucleus is central with round to oval shape and often obscured by cytoplasmic granules. These are small to medium size spherical cells (Rupley, 1999) measuring from 4.9 to $19.9 \mu \mathrm{m}$ in diameter (Morgulis, 2002).

The aim of this study was to describe values and aspects of Rhea americana's hematology (Rheidae Family) and to analyze morphologically and morphometrically the erythrocyte and leukocyte fractions and the thrombocytes.

\section{Material and Methods}

Fifty-eight adult rheas of both sexes were used in this study. Forty-eight were from a conservatory breeding located in the city of Cachoeiro do Itapemirim $\left(20^{\circ} 50^{\prime} 58^{\prime \prime} \mathrm{S}\right.$, $41^{\circ}$ 6' 48" W) in Espírito Santo State, and 10 were from an ecological park in the city of São Carlos $\left(22^{\circ} 0 ' 55^{\prime}\right.$ ' S, $47^{\circ} 53$ ' 28' W) São Paulo State, both in Brazil. The blood samples were collected by puncturing the brachial vein and placed in glass tubes containing EDTA, labeled and stored in a refrigerator until processing on the same day.

Total Red Blood Cells (RBC) counts were performed using the Hematology Cell Counter MS4 ${ }^{\circledR}$ (Melet Schloesing Laboratories, France). The Packed Cell Volume (PCV) was determined by the microhematocrit method in capillary tubes and centrifuged at 12,000 g for 5 minutes. Hemoglobin concentration $(\mathrm{Hb})$ was determined using the reagent from the brand Labtest ${ }^{\circledR}$ and evaluated using a spectrophotometer (Biosystems ${ }^{\circledR}$-BTS 310) with the absorbance measured at $540 \mathrm{~nm}$. The calculated erythrocyte indices of mean corpuscular volume (MCV), mean corpuscular hemoglobin $(\mathrm{MCH})$ and mean corpuscular hemoglobin concentration (MCHC) were calculated using the results determined from the red fraction (Jain et al., 2000), and the values were expressed in femtoliters (fL), picograms (pg) and grams per deciliter $(\mathrm{g} / \mathrm{dL})$, respectively.

Total White Blood Cell (WBC) counts were performed by a manual method using blood diluted on $0.01 \%$ toluidine blue stain (Blue-McLendon and Green, 2010) and the results were expressed in units per microliter $(\mu \mathrm{L})$. Thin smears on glass slides were made immediately after the blood collection to avoid any interference on cell 
structure. Differential WBC counts, using an average of 200 cells, were made from blood films stained with Fast Panoptic and examined under an optical microscope with a 100X objective (immersion oil). Images were captured using a digital camera (Canon PowerShot A640) with the aid of a computer and the Software Zeiss Axion Vision. Erythrocytes, leukocytes and thrombocytes were identified and morphologically characterized, and their length and width were measured (increase 100x). Five cells of each type were measured per blood films.

Fibrinogen was measured by the capillary method after denaturation of the total plasma protein (TPP) at $56{ }^{\circ} \mathrm{C}$ for 3 minutes, and both were read in a refractometer (Jain, 1993). Values were expressed in $\mathrm{mg} / \mathrm{dL}$ and $\mathrm{g} / \mathrm{dL}$, respectively.

For statistical analysis we used Student's t-test to qualitatively and quantitatively analyze the components of the rhea blood. All of the calculations were performed using the software SAEG (Statistical Analysis System version 9.1).

\section{Results}

The total of collected samples was 58, but two had hemolysis problem and another sample coagulated and couldn't be analyzed the quantification of erythrocyte in the erythrocyte MS $4{ }^{\circledR}$ counter. On the other hand, those with hemolysis problem had PCV and Hb measured (Table 1). Concerning WBC counts, 16 samples had staining problems and examination on Neubauer chamber; this results were unreliable and then were discarded (Table 1).

The mean hematologic parameters for the red and white fractions and biochemical from the rheas raised in captivity on two farms in Brazil can be seen in Table 1. The protein values from two birds from Espirito Santo were discarded due to lack of confiability in the results and in others 10 birds from property in São Paulo these parameters were not measured. Thus, the total number of samples was 46 (Table 1).

The mean measurements, standard deviations and cell numbers measures are shown in Table 2. The morphological

Table 1. Hematological values for adult rheas, Rhea americana. in captive breeding from Brazil.

\begin{tabular}{|c|c|c|c|c|}
\hline \multirow{2}{*}{$\begin{array}{l}\text { EVALUATED } \\
\text { PARAMETERS }\end{array}$} & \multicolumn{2}{|r|}{ Present study } & \multicolumn{2}{|c|}{ Other authors } \\
\hline & $\mathbf{n}^{1}$ & & $\begin{array}{l}\text { Blue-McLendon } \\
\text { and Green (2010) }\end{array}$ & Fortes et al. (2009) \\
\hline $\mathrm{RBC}\left(\mathrm{x} 10^{6} / \mu \mathrm{L}\right)$ & $55^{2}$ & $1.21 \pm 0.80(0.29-3.10)$ & $2.25 \pm 0.1$ & $2.39 \pm 0.52(1.60-2.90)$ \\
\hline PCV $(\%)$ & $56^{3}$ & $40.78 \pm 4.47(31-51)$ & $41.6 \pm 1.9$ & $39.6 \pm 5.48(30-45)$ \\
\hline $\mathrm{Hb}(\mathrm{g} / \mathrm{dL})$ & 56 & $10.44 \pm 1.39(7.80-13.33)$ & $13.4 \pm 0.45$ & $16.27 \pm 4.40(9.40-26.00)$ \\
\hline MVC (fL) & 55 & $44.71 \pm 20.09(14.48-106.90)$ & $18.5 \pm 5.9$ & $17.1 \pm 3.44(12.1-25)$ \\
\hline $\mathrm{MCH}(\mathrm{pg})$ & 55 & $113.53 \pm 52.94(40.73-286.81)$ & $59.56^{*}$ & $70 \pm 19.70(43-99)$ \\
\hline $\mathrm{MCHC}(\mathrm{g} / \mathrm{dL})$ & 56 & $25.64 \pm 2.49(18.18-33.06)$ & $32 \pm 0.01$ & $42.1 \pm 12.78(24-63)$ \\
\hline $\mathrm{WBC}(/ \mu \mathrm{L})$ & $42^{4}$ & $12,072 \pm 4.116(5.35-24.40)$ & $13,600 \pm 3,300$ & $8,683 \pm 4,860(3,000-18,500)$ \\
\hline Heterophils (\%) & 58 & $64.10 \pm 9.90(37-88)$ & $(59.5 \pm 33.3)^{*}$ & $62.09 \pm 8.58(52-78)$ \\
\hline Eosinophils (\%) & 58 & $2.05 \pm 2.06(0-10)$ & $(1.47 \pm 1.47)^{*}$ & $2.18 \pm 1.02(0.30-3.10)$ \\
\hline Monocytes (\%) & 58 & $6.40 \pm 2.99(0-15)$ & $(3.68 \pm 2.94)^{*}$ & $6.01 \pm 2.99(1.40-9.70)$ \\
\hline Lymphocytes (\%) & 58 & $26.93 \pm 9.62(6-50)$ & $(31.6 \pm 23.2)^{*}$ & $27.04 \pm 6.60(17.70-34.30)$ \\
\hline Basophils (\%) & 58 & $0.52 \pm 1.27(0-6)$ & $(3.68 \pm 3.68)^{*}$ & $2.69 \pm 1.43(1.00-6.00)$ \\
\hline TPP (g/dL) & $46^{5}$ & $6.41 \pm 0.95(4.60-9.20)$ & - & - \\
\hline Fibrinogen (mg/dL) & 46 & $297.83 \pm 249.88(100-1400)$ & - & - \\
\hline
\end{tabular}

${ }^{1}$ Number of samples. ${ }^{2}$ From the 58 samples collected three were not analyzed; two due to hemolysis problems and one due to clotting. ${ }^{3}$ From the 58 samples collected, two that had hemolysis were not analyzed. ${ }^{4}$ Problems with staining and observation of the cell morphology in Neubauer chamber led to the discard of 16 samples. ${ }^{5}$ Two samples were not analyzed in one property because of lack of trust in the results and other 10 samples were not collected from another property. *Values calculated from authors data.

Table 2. Morphometry of blood cells of adult rheas, Rhea americana, in captive breeding from Brazil.

\begin{tabular}{|c|c|c|c|c|}
\hline \multirow{2}{*}{ Cells } & \multirow{2}{*}{$\mathbf{n}^{1}$} & \multicolumn{2}{|c|}{ Measurements in micrometers } & \multirow{2}{*}{$\begin{array}{c}\text { Morphometric } \\
\text { Index } \\
\end{array}$} \\
\hline & & Length & Width & \\
\hline Erythrocytes & 290 & $14.03 \pm 1.04(11.15-17.00)$ & $8.47 \pm 0.89(1.87-12.35)$ & $1.68 \pm 0.38(7.28-1.05)$ \\
\hline Heterophils & 289 & $12.93 \pm 1.57(9.04-20.24)$ & $11.56 \pm 1.26(7.92-15.15)$ & $1.12 \pm 0.13(1.00-2.26)$ \\
\hline Eosinophils & 231 & $13.04 \pm 1.69(8.95-19.29)$ & $11.15 \pm 1.35(7.73-15.32)$ & $1.18 \pm 0.17(1.00-2.28)$ \\
\hline Monocytes & 273 & $15.62 \pm 2.64(7.14-24.47)$ & $13.50 \pm 2.16(7.04-21.20)$ & $1.16 \pm 0.14(1.00-1.70)$ \\
\hline Lymphocytes & 290 & $8.71 \pm 1.92(5.69-16.34)$ & $7.44 \pm 1.65(4.41-13.25)$ & $1.18 \pm 0.17(1.11-1.99)$ \\
\hline Basophils & 50 & $11.49 \pm 1.24(8.96-14.75)$ & $10.32 \pm 1.06(8.23-13.26)$ & $1.11 \pm 0.09(1.01-1.39)$ \\
\hline Thrombocytes & 290 & $8.45 \pm 1.48(5.46-13.96)$ & $6.70 \pm 1.31(3.54-10.69)$ & $1.29 \pm 0.24(1.00-2.50)$ \\
\hline
\end{tabular}

${ }^{1}$ Number of cells, considering, at least, five cells of each type per smear. 
variances that allow the identification of different cells and the polymorphisms between the cells during their development are described below.

Examination of the erythrocytes showed that the cells were nucleated and had oval to elliptical nucleus of various sizes. The nuclei were centrally located and were dark purple with uniformly clumped chromatin and a abundant and brown cytoplasm (Figure 1E). We also found rounded immature erythrocytes (Figures 1A-1D) similar to basophilic erythroblasts (rubricytes) that had a very thin basophilic cytoplasm forming a small ring around the nucleus, which was generally round (Figure 1A). The metarubricytes (polychromatic erythroblasts) also had a basophilic cytoplasm, but it was less round and more abundant than in the rubricytes. Their nuclei were round with partially condensed nuclear chromatin (Figure 1B). Young polychromatic erythrocytes were observed. These cells had a less basophilic cytoplasm than the previously mentioned immature cells, but with a larger cytoplasm, an elongated nucleus with very condensed chromatin and a slightly oval cellular shape (Figure 1C). The advanced-stage polychromatic erythrocytes were identified by their non-basophilic cytoplasms and their 1/1 ratio, where both the nucleus and the cytoplasm were oval (Figure 1D). A single binucleated erythrocyte was seen in the blood smear of one bird from São Paulo (Figure 1F).

The heterophils were the predominant circulating leukocytes found in rheas. These appeared as round cells with monolobular, bilobular or trilobular nuclei located off-center or on the periphery, purple colored with darker regions containing condensed chromatin. The cytoplasm was clear with red or orange spindle- (Figure 2A), rod- or sphere-shaped granules. The cytoplasmic granules sometimes covered the nucleus, blocking the complete visualization of the heterophils nucleus (Figure 2B). Vacuoles were seen in the cytoplasm of some heterophils (Figure 2C).

Eosinophils had a round shaped and clear-grey cytoplasm (Figure 2D) with round granules that showed acidophilic staining and were homogeneously distributed in clusters or sometimes on the nucleus. These granules were pink and orange in color and had a more vibrant tone than the heterophils. The nucleus was polymorphic with two (Figure 2E) or three lobes (Figure 2F), located either centrally or peripherally and violet with condensed chromatin.
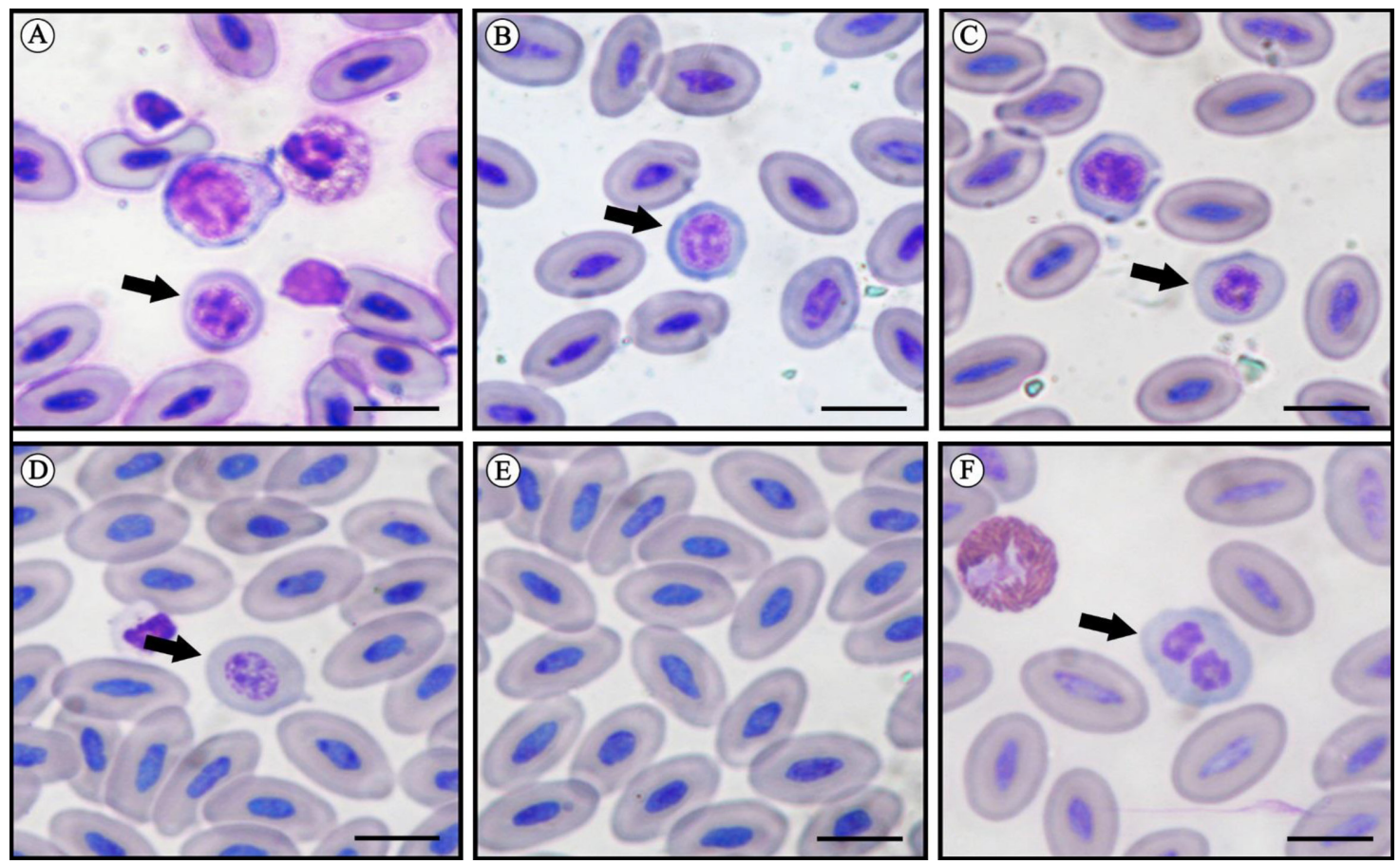

Figure 1. Blood smears from rheas, Rhea Americana showing erythrocytes, stained by the Fast Panotic method. (A) Basophilic erythroblast (rubricytes), with low and markedly basophilic cytoplasm, forming a thin border around the rounded nucleus (arrow); (B). Metarrubricyte or polychromatic erythroblast (arrow), where the cytoplasm has a slight loss of its rounded shape, but with the nucleus more rounded than the rubricyte and presenting the nuclear chromatin in a condensation process; (C) Young polychromatic erythrocyte where the cytoplasm is less basophilic than metarrubricyte, but with greater cytoplasmic volume, elongated nucleus with slightly more condensed chromatin and the cell with a slightly oval shape (arrow); (D) Polychromatic erythrocyte in an advanced stage (arrow) without basophilic dominance, but with a ratio of cytoplasm and nucleus of $1: 1$, where both the nucleus and the cell present an oval shape; (E) Mature erythrocytes, of varying size, with an oval to elliptical nucleus, centrally located with dark purple coloration, chromatin evenly grouped and abundant cytoplasm; (F) Binucleated erythrocyte in mitosis (arrow). Bars: $10 \mu \mathrm{m}$. 

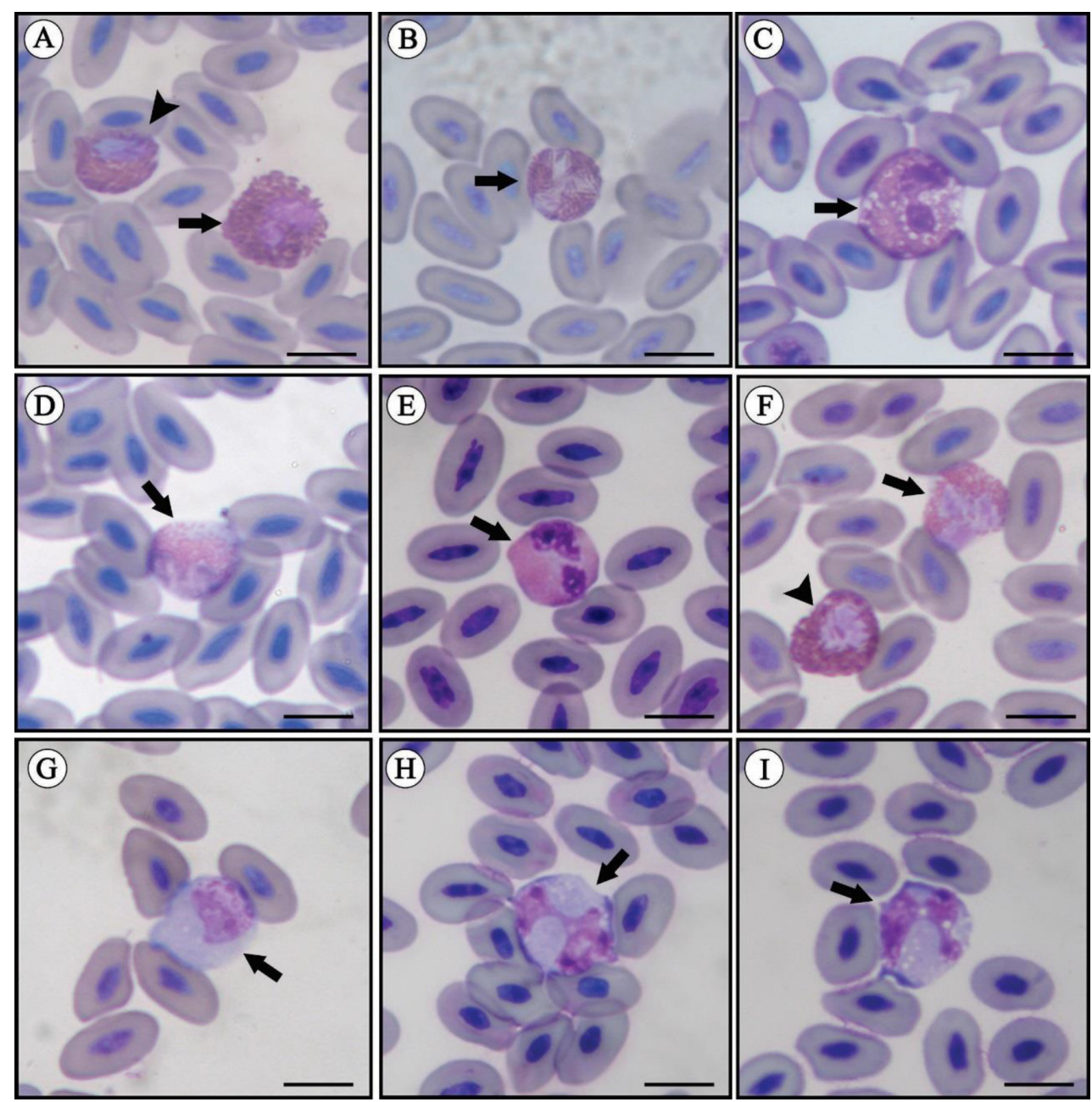

Figure 2. Blood smears from rheas, Rhea americana stained by the Fast Panoptic method. (A-C) Heterophils; (D-F) Eosinophils; (G-I) Monocytes. (A) Binucleated heterophil, with an eccentric localization, polymorphonuclear, with granules in the cytoplasm spindle-shaped (arrow). Heterophil without lobulation (head arrow); (B) Heterophil with cytoplasmic granules above the nucleus, avoiding the perfect view of the nucleus (arrow); (C) Heterophil with vacuoles in the cytoplasm (arrow). (D) Eosinophil with a spherical shape, light gray cytoplasm with spherical granules colored in an intense acidophilic way and evenly distributed in a grouped manner, nucleus bilobulated with an eccentric location (arrow); (E) Bilobulated eosinophil with granules homogeneously distributed in the cytoplasm and peripheral nucleus with condensed chromatin (arrow); (F) Arrow shows a trilobular eosinophil with granules with a more intense coloration than the heterophil (head arrow); (G) Monocyte without nucleus division located in eccentric position presenting loose chromatin with small condensed areas (arrow); (H) Monocyte bilobulated; (arrow); (I) Monocyte bilobulated with small discrete vacuoles in the nucleus and cytoplasm (arrow) Bars: $10 \mu \mathrm{m}$.

The observed monocytes were large cells with a round or irregular shape. These had nuclei without divisions (Figure 2G) or were bilobular (Figure 2H), and were pleomorphic, localized off center or in the center and had loose chromatin and small areas of condensed chromatin. The cytoplasm was blue-grey and had small discrete vacuoles that were also found in the nucleus (Figure 2I). Those were the larger leukocytes seen in the blood smears of rheas (Table 2).

Lymphocytes found had a round shape and different sizes. The nucleus was non-lobed, with rounded shape, located slightly to one side or at the center of the cell, purple in color with areas of condensed chromatin. Homogeneous cytoplasm, stained in blue, ranged in number of low to moderate, being scarce especially in small lymphocytes (Figure 3A) and increasing in volume in larger lymphocytes (Figure 3B). Furthermore, some lymphocytes were found with cytoplasmic protrusions (Figure 3C).

Basophils were round in the rheas. The nucleus did not have any lobes, it was located off-center or in the center, and it was round and pink-(Figure 3D) or blue-colored (Figure 3E) with loose chromatin. The cytoplasm was filled 

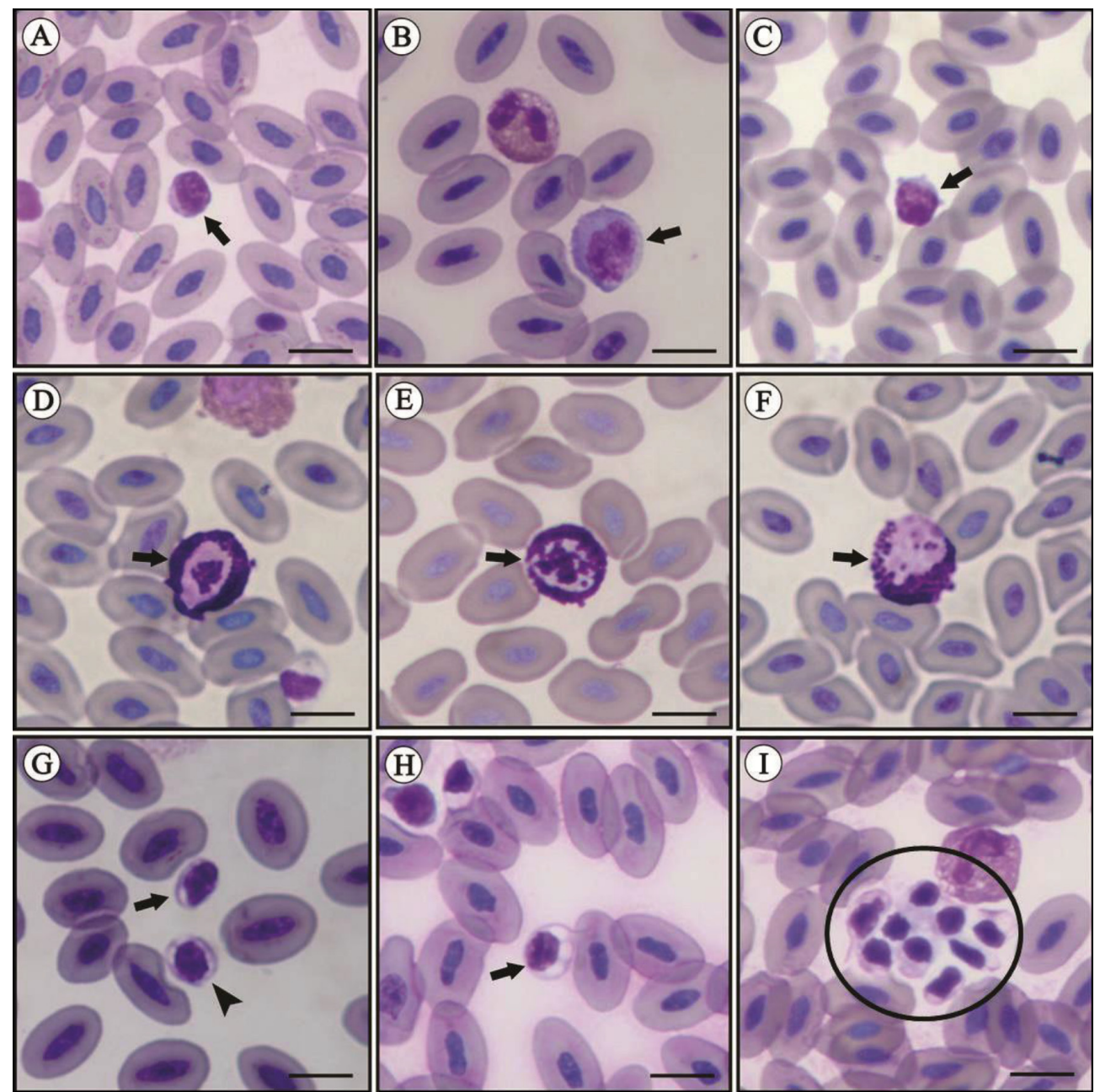

Figure 3. Blood smears from rheas, Rhea americana stained by the Fast Panotic method. (A-C) Lymphocytes; (D-F) Basophils; (G-I) Thrombocytes. (A) Small rounded lymphocyte (arrow) with a rounded non-lobulated nucleus, located slightly to one side of the cell with areas of condensed chromatin and cytoplasm homogeneous and sparse; (B) Medium lymphocyte (arrow) with an abundant cytoplasmatic content; (C) Lymphocyte with cytoplasmatic protrusions (arrow), giving it an amoeboid aspect; (D) Spherical basophils with nucleus without lobulations and centrally located and cytoplasm filled with large, basophilic and spherical granules, also found above the nucleus; (E) Spherical basophil (arrow), with nucleus without lobulation, located in the center of the cell and cytoplasm filled with granules that are scattered in the nucleus; (F) Rounded basophil with eccentric nucleus, cytoplasm with rounded granules and some granules scattered in the nucleus; (G) Mononucleated thrombocyte, oval in shape (arrow), nucleus with the same shape of the cell with condensed chromatin and scarce and transparent cytoplasm. Rounded thrombocyte (head arrow) with a scarce and hyaline cytoplasm; (H) Thrombocytes with three vacuoles in the cytoplasm (arrow); (I) Cluster of thrombocytes (circle). Bars: $10 \mu \mathrm{m}$.

with basophilic, large and round granules (Figure 3F) that frequently obscured the nucleus.

Thrombocytes appeared as small, mononucleated cells that were round or oval (Figure 3G). The shape of the nucleus corresponded to the shape of the cell. It was located in the center or on the periphery and was dark purple in color with clumped chromatin. The cytoplasm was small and clear. We commonly saw one or more vacuoles in the cytoplasm (Figure $3 \mathrm{H}$ ). We also occasionally found clusters of thrombocytes (Figure 3I). These were the least common blood cell types found in rheas (Table 1).

\section{Discussion}

In this study, we sought to evaluate blood components in rheas with the goal of determining the hematologic parameters in captive animals. Investigation of these parameters is impeded by the small number of farms and the difficulties related to the stress that these birds suffer during collection. For these reasons, only a few studies have been conducted on this topic, and those that do exist have used a small number of animals (Blue-McLendon and Green, 2010; Fortes et al., 2009). 
The mean hematologic values in the studied rheas were similar to the reference values found by Blue-McLendon and Green (2010), with some differences in the red fraction. These differences include lower RBC counts, lower PCV and $\mathrm{MCHC}$ values and higher $\mathrm{MCV}$ values. Our results were influenced by the low values measured in the birds from Espírito Santo State. Similar to the results from the red fraction, the data from the white fraction drawn from rheas in Brazil were similar to the standard established by Blue-McLendon and Green (2010). Therefore, the data from the red and white fractions for birds can be considered reference values for rheas raised in Brazil.

Contrary to what we found in our evaluation of the red and white fractions, the protein values were higher than those reported by Kaneko et al. (1997) for birds. High protein values are found in birds during severe inflammation (Charles Noriega, 2000), and factors such as age, season and sickness can also influence protein levels (Lumeij, 1997). However, these factors were not found to cause increased protein levels in rheas from Espírito Santo State.

Morphometrically, the mean values for erythrocyte measurements were within the ranges observed by Benez (2001) for birds in general, and our results support the finding of this author that these cells are larger in the Rheiform order, where some erythrocytes are as large as $17 \mu \mathrm{m}$ in lenght and $12.35 \mu \mathrm{m}$ in width when compared to the dimensions of $11-16 \mu \mathrm{m}$ in lenght and 6-10 $\mu \mathrm{m}$ in width generally found in birds.

The distinction between the length and width of white blood cells in birds is impeded by their morphology. For example, the mean morphometric index (MI) calculated for all of the white blood cells in rheas is close to one. This may explain why the length and width of these cells is reported as the measured diameter (Lucas and Jamroz, 1961; Nirmalan et al., 1972; Campbell and Dein, 1984; Banks, 1993; Coles et al, 1998; Jain et al., 2000).

The majority of rheas's white blood cells had mean lengths and widths larger than the reference values for birds reported in the literature, with the exception of the lymphocytes. However, were found heterophils with length and width of 9.04 and $7.92 \mu \mathrm{m}$, which is within the range of reference values of 5.1 and $11.4 \mu \mathrm{m}$ in diameter for these cells in birds (Lucas and Jamroz, 1961; Nirmalan et al., 1972; Campbell and Dein, 1984; Jain et al., 2000). This was also observed for monocytes, with some cells having a length and width far below the $12 \mu \mathrm{m}$ diameter reported by Lucas and Jamroz (1961) for avian monocytes.

The lowest values observed of eosinophils were 8.95 and $7.73 \mu \mathrm{m}$ in length and width, which are consistent with the eosinophil diameters reported by Campbell and Dein (1984) for birds. Morgulis (2002) reported that the diameters of avian basophils ranges from 4.9 to $19.9 \mu \mathrm{m}$, and contrary to what happened with the other cells of the white series, the mean length and width was within these measurements. Of all the cell types observed, only the lymphocytes (Coles et al., 1998) and thrombocytes (Lucas and Jamroz, 1961) had morphometric measurements that were within the range described in the literature.
The blood cells from $R$. americana had the same characteristics seen in cells from other vertebrates, including with all nucleated cells, which is in agreement with some authors (Banks, 1991; Garcia-Navarro and Pachaly, 1994; Rupley, 1999; Huchzermeyer, 2000; Benez, 2001; Santos, 2001; Goulart, 2006; Fortes et al., 2009; Blue-McLendon and Green, 2010). The erythrocytes observed in the smears had nucleus and shape oval to elliptical, which differs from what was reported by Banks (1991) and Benez (2001) for birds and by Blue-McLendon and Green (2010) for ratites that only found oval cells with oval nuclei, as did Pacheco et al. (2000c) for partridges (Rhynchotus ruflescens) and Pereira et al. (2003) for the Brazilian Duck (Amazonetta brasiliensis). Arnall and Keymer (1975), Banks (1993) and Rupley (1999) for birds, Pereira et al. (2004) for the blackish rail (Pardirallus nigricans) and Fortes et al. (2009) for rhea (R. americana) observed only cells with shape and elliptical nucleus. In agreement with Fortes et al. (2009), we found that these cells have nucleus with condensed chromatin and an abundant cytoplasm. However, the cytoplasm observed in the present study had a brownish color, which is different than the acidophilic cytoplasm found by this same author and by other authors including Santos (2001) in the carijo hawk and by Goulart (2006) in blue-fronted parrots. According to some authors, erythrocytes have a pink-orange cytoplasm (Banks, 1993; Rupley, 1999; Bounous and Stedman, 2000; Blue-McLendon and Green, 2010).

Some immature erythrocytes were found in the rhea blood smears. According to some authors (Lucas and Jamroz, 1961; Sturkie, 1976; Hodges, 1977; Van Der Heyden, 1994; Campbell, 1995; Jain et al., 2000), immature cells are commonly found in smears from healthy birds without necessarily indicating a pathological change. Only one erythrocyte was seen in mitosis. Some authors (Lucas and Jamroz, 1961; Sturkie, 1976; Hodges, 1977; Van Der Heyden, 1994; Campbell, 1995; Jain et al., 2000) reported that binucleated erythrocytes are occasionally seen, but when present in large numbers, it may suggest neoplastic processes, viral infections or genetic disorders.

The heterophils in the rheas contain three types of cytoplasmic granules (spindle, rod and sphere shaped), which is contrary to the report by Bonadiman et al. (2009) for ostriches (Struthio camelus), where only rod-shaped granules were found. Fortes et al. (2009) observed only cytoplasmic granules of various elongated shapes (spindle and stick shaped) in heterophils from $R$. americana. Banks (1991) reported rod and spindle shaped granules in birds in general. In the carijo hawk, Buteo magnirostris, spherical and rod shaped cytoplasmic granules were found (Santos, 2001). Some authors observed in other birds only heterophils with lobed nucleus, which disagrees with the results presented here where also were found nuclei without lobes (Banks, 1991; Maxwell and Robertson, 1998; Rupley, 1999; Santos, 2001; Pereira et al., 2003, 2004; Fortes et al., 2009; Blue-McLendon and Green, 2010). As observed by several authors (Banks, 1991; Campbell, 1995; Maxwell and Robertson, 1998; Rupley, 
1999; Charles Noriega, 2000; Pacheco et al., 2000a, b; Pereira et al., 2003, 2004) heterophils are round cells. In the current study, the nuclei had condensed chromatin and were located off-center or in the periphery as reported by some authors (Banks, 1991; Maxwell and Robertson, 1998; Rupley, 1999; Santos, 2001; Fortes et al., 2009; Blue-McLendon and Green, 2010).

Anderson and Stephens (1970), Elsbach (1980), Evans et al. (1994), Campbell (1995) and Kokosharov (1998) reported that heterophils are the most common cells in avian blood smears. However, Charles Noriega (2000) reported that the most common type of blood cell in the majority of avian species is the lymphocyte, with heterophils as the second most common blood cell type, and in ostrich and pheasant, the most abundant are the heterophils. Based on this study, we can confirm that heterophils are the most common blood cell types in rheas, whereas lymphocytes are the second most common.

As observed in birds (Banks, 1991; Rupley, 1999; Benez, 2001), ratites (Huchzermeyer, 2000; Blue-McLendon and Green, 2010), carijo hawks (Santos, 2001) and rheas (Fortes et al., 2009), eosinophils found in rheas in the present study may also have bilobular or trilobular nucleus. Other descriptions made in this study concerning eosinophils are in agreement with the authors cited above. Bonadiman et al. (2009) rarely observed eosinophils in ostriches.

We did not observe acidophilic cytoplasmic granules in rhea monocytes as reported by Banks (1991) in birds in general and Bonadiman et al. (2009) in ostriches. In contrast with Bonadiman et al. (2009), monocytes with bilobular nucleus were found. As observed in birds in general (Lucas and Jamroz, 1961), carijo hawk (Santos, 2001) and rheas (Fortes et al., 2009), we frequently found cytoplasmic vacuoles in monocytes. Goulart (2006) rarely observed cytoplasmic vacuoles in blue-fronted parrots (Amazona aestiva). Blue-McLendon and Green (2010) only saw round nucleus in ratite monocytes in contrast with this study where pleomorphic nuclei were found.

The reported characteristics for lymphocyte lineage cells in rheas agrees with what has already been reported for lymphocytes by other authors (Lucas and Jamroz, 1961; Hodges, 1977; Banks, 1991; Campbell, 1995; Rupley, 1999; Huchzermeyer, 2000; Benez, 2001; Santos, 2001; Junqueira and Carneiro, 2004; Goulart, 2006; Fortes et al., 2009; Blue-McLendon and Green, 2010). As Goulart (2006) observed in blue-fronted parrots, were found lymphocytes with cytoplasmic protrusions, which confer an amoeboid appearance to the cell.

Contrary to Benez (2001), who only observed basophils with clear blue nucleus in birds in general, the basophil nucleus observed in rhea blood smears in this study not only had blue coloration but also had more acidophilic nuclei with a pink tone. Areas of condensed chromatin were not seen in the basophil nucleus of rheas but this characteristic has already been reported in birds (Banks, 1991; Rupley, 1999; Benez, 2001; Junqueira and Carneiro, 2004; Blue-McLendon and Green, 2010), ratites (Huchzermeyer, 2000), carijo hawk (Santos, 2001), blue-fronted parrots
(Goulart, 2006) and rheas (Fortes et al., 2009). Differently from cited by these same authors, basophils cytoplasm in rheas were full of granules. Goulart (2006) found lobular and non-lobular nuclei in basophils from blue-fronted parrots, and Bonadiman et al. (2009) observed basophils with highly lobular nucleus in ostriches, disagreeing with the observations in rheas in this study where only nuclei without lobes were seen.

In rheas bloods, round to oval thrombocytes were observed, unlike Fortes et al. (2009), who described thrombocytes in $R$. americana with an exclusively elliptical shape, and Benez (2001) and Goulart (2006) who found only oval shaped cells, Pereira et al. (2003) who reported thrombocytes that were more rectangular in Brazilian ducks and Pereira et al. (2004), who reported rectangular thrombocytes in the blackish rail. In contrast with Santos (2001) for carijo hawk (Buteo magnirostris), in this study, two azurophilic granules were not observed in one of the thrombocyte poles in rhea. Rupley (1999) reported thrombocytes with a clear-blue to pale cytoplasm and thin red granules, and Maxwell and Robertson (1998) described cytoplasm and specific basophilic granules in large numbers in birds, disagreeing with this study, where were found hyaline cytoplasm without granules.

\section{Conclusion}

Rhea's blood has the same components observed in other birds blood, including domestic ones, raized for commercial means. The cells, including red and white series are bigger than in other birds, but, it is not possible to differ rhea's blood cells from those of other birds in blood smears only by size. Rhea's leukocytes have components and coloration distinct as observed for other birds leukocytes, but there is no other components or staining aspects exclusive for rheas's leukocytes.

\section{References}

ANDERSON, E.L. and STEPHENS, J.F., 1970. Changes in the differential leukocyte count of chicks inoculated with Salmonella. Applied and Environmental Microbiology, vol. 19, no. 5, pp. 726-730. PMid:5422304

ARNALL, L. and KEYMER, I.F., 1975. Bird diseases. London: Baillière Tindall. $528 \mathrm{p}$

BANKS, W.J., 1991. Sangue. In: W.J. BANKS. Histologia veterinária aplicada. 2nd ed. São Paulo: Manole, pp. 87-203.

BANKS, W.J., 1993. Applied veterinary histology. 3rd ed. St. Louis: Mosby. $527 \mathrm{p}$.

BENEZ, S.M., 2001. Aves: criação, clínica, teoria, prática. Silvestres, ornamentais, avinhados. 3rd ed. São Paulo: Robe. 522 p.

BLUE-MCLENDON, A. and GREEN, R.A., 2010. Hematology of ratites. In: D.J. WEISS and K.J. WARDROP, eds. Schalm's veterinary hematology. 6th ed. Ames: Lippincott Williams \& Wilkins, pp. 987-993.

BONADIMAN, S.F., STRATIEVSKY, G.C., MACHADO, J.A., ALBERNAZ, A.P., RABELO, G.R. and DAMATTA, R.A., 2009. 
Leukocyte ultrastructure, hematological and serum biochemical profiles of ostriches (Struthio camelus). Poultry Science, vol. 88, no. 11, pp. 2298-2306. http://dx.doi.org/10.3382/ps.2009-00176. PMid:19834079.

BOUNOUS, D.I. and STEDMAN, N.L., 2000. Normal avian hematology: chicken and turkey. In: B.V. FELDMAN, J.G. ZINKL and N.C. JAIN, eds. Schalm's veterinary hematology. Philadelphia: Williams \& Wilkins, pp. 1145-1154.

CAMPBELL, T.W. and DEIN, F.J., 1984. Avian hematology: the basics. Veterinary Clinics of North America Small Animals Practioners, vol. 14, no. 2, pp. 223-248. http://dx.doi.org/10.1016/ S0195-5616(84)50031-X. PMid:6610969.

CAMPBELL, T.W., 1995. Avian hematology and cytology. 2nd ed. Ames: Iowa State University Press. 104 p.

CARDOSO, A.L.S.P and TESSARI, E.N.C., 2003. Estudo dos parâmetros hematológicos em frangos de corte. Arquivo do Instituto de Biologia, vol. 70, no. 4, pp. 419-424.

CHARLES NORIEGA, M.L.V.C., 2000. Apuntes de hematología aviar: material didático para curso de hematologia aviária. México: Departamento de Produccíon Animal: Aves, Universidad Nacional Autónoma de México. 70 p. Apostila mimeo.

COLES, B.H., KRAUTWALD-JUNHANNS, M.E. and HERRMAN, T.J., 1998. Self-assessment picture tests: avian medicine. St. Louis: Mosby. 212 p.

ELSBACH, P., 1980. Degradation of microorganisms by phagocytic cells. Revisable Infectious Diseases, vol. 2, no. 1, pp. 106-128. http://dx.doi.org/10.1093/clinids/2.1.106. PMid:6994199.

EVANS, E.W., BEACH, G.G., WUNDERLICH, J. and HARMON, B.G., 1994. Isolation of antimicrobial peptides from avian heterophils. Journal of Leukocyte Biology, vol. 56, no. 5, pp. 661-665. PMid:7964174.

FORTES, E.A.M., SOUSA, A.F., ALMEIDA, E.C.S., CONDE JÚNIOR, A.M. and MOURA, W.L., 2009. Morfologia das células do sangue periférico em emas (Rhea americana). Brazilian Journal of Veterinary Research and Animal Science, vol. 46, no. 3 , pp. 215-221.

FUDGE, A.M., 1997. Avian clinical pathology-hematology and chemistry. In: R.B. ALTMAN, S.L. CLUB, G.M. DORRESTEIN and K. QUESENBERRY, eds. Avian medicine and surgery. Philadelphia: WB Saunders, pp. 142-157.

GARCIA-NAVARRO, C.E.K. and PACHALY, J.R., 1994. Manual de hematologia veterinária. São Paulo: Varela, pp. 135-142. cap. 13.

GIANNONI, M.L., 1996. Emus and ostriches: an alternative for the farmer. Jaboticabal: FUNEP. 49 p.

GOULART, C.E.S., 2006. Valores hematológicos de referência para papagaios verdadeiros (Amazona aestiva-Psittacidae) mantidos em cativeiro. Belo Horizonte: Departamento de Medicina Veterinária Preventiva, Escola de Veterinária, Universidade Federal de Minas Gerais, 80 p. Masters Dissertation.

GREEN, R.A. and BLUE-MCLENDON, A., 2000. Ratite hematology. In: B.V. FELDMAN, J.G. ZINKL and N.C. JAIN, eds. Schalm's veterinary hematology. 5th ed. Baltimore: Lippincott Williams \& Wilkins, pp. 1201-1206.

HODGES, R.D., 1977. Normal avian (poultry) haematology. In: R.K. ARCHER and L.B. JEFFCOTT, eds. Comparative clinical haematology. Oxford: Blackwell Scientific Publications, pp. 483-517.
HUCHZERMEYER, F.W., 2000. Doenças de avestruzes e outras ratitas. 2nd ed. Jaboticabal: Funep. 392 p.

JAIN, N.C., 1993. Essentials of veterinary hematology. Philadelphia: Lea \& Febiger. $417 \mathrm{p}$.

JAIN, N.C., FELDMAN, B.F. and ZINKL, J.G., 2000. Schalm 's veterinary hematology. 5th ed. Philadelphia: Lea \& Febiger. 538 p.

JUNQUEIRA, L.C. and CARNEIRO, J., 2004. Células do sangue. In: L.C. JUNQUEIRA and J. CARNEIRO. Histologia básica. 10th ed. Rio de Janeiro: Guanabara Koogan, pp. 224-237.

KANEKO, J.J., HARVEY, J.W. and BRUSS, M.L., 1997. Clinical biochemistry of domestic animals. 5th ed. San Diego: Academic Press. 932 p.

KOKOSHAROV, T., 1998. Changes in the white blood cells and specific phagocytosis in chicken with experimental acute fowl typhoid. Veterinarski Arhiv, vol. 68, pp. 33-38.

LUCAS, A.M. and JAMROZ, C., 1961. Atlas of avian hematology. Washington: Department of Agriculture. $271 \mathrm{p}$.

LUMEIJ, J.T., 1997. Avian clinical biochemistry. In: J.J. KANEKO, J.W. HARVEY and M.L. BRUSS, eds. Clinical biochemistry of domestic animals. 5th ed. San Diego: Academic Press. 932 p.

MAXWELL, M.H. and ROBERTSON, G.W., 1998. The avian heterophil leukocyte: a review. World's Poultry Science Journal, vol. 2, no. 2, pp. 155-178. http://dx.doi.org/10.1079/WPS19980012.

MORGULIS, M.S., 2002. Imunologia aplicada. In: M. MACARI, R.L. FURLAN and E. GONZALES. eds. Fisiologia aviária aplicada a frangos de corte. Jaboticabal: Funep/Unesp, pp. 248-316.

NIRMALAN, G.P., ATWAL, O.S. and CARLSON, H.C., 1972. Ultra structural studies on leukocytes and thrombocytes in circulating blood of japanese-quail. Poultry Science, vol. 51, no. 6, pp. 2050-2055. http://dx.doi.org/10.3382/ps.0512050. PMid:4660986.

PACHECO, M.R., BARALDI-ARTONI, S.M., VARELLA, M.H.C., ARAUJO, M.L., SANTOS, D.A.S., FERREIRA, N. and RODOLPHO, D., 2000a. Efeito de diferentes níveis protéicos sobre a morfologia de hemácias e leucócitos de codornas (Cortunix cortunix japonica). Brazilian Journal of Morphological Sciences, vol. 17, suppl., pp. 99.

PACHECO, M.R., BARALDI-ARTONI, S.M. and FERREIRA, N., 2000b. Estudo morfológico de hemácias e leucócitos de perdizes (Rhynchotus ruflescens) mantidas em cativeiro. Brazilian Journal of Morphological Sciences, vol. 17, suppl., pp. 113.

PACHECO, M.R., BARALDI-ARTONI, S.M. and FERREIRA, N., 2000c. Estudo morfométrico de hemácias de perdizes (Rhynchotus ruflescens) mantidas em cativeiro. Brazilian Journal of Morphological Sciences, vol. 17, suppl., pp. 114.

PEREIRA, M.E., SILVEIRA, A.F., GUEDES, A.G.P. and SILVEIRA, S.O., 2003. Hemocitometria em marreca do pé vermelho (Amazonetta brasiliensis). Arquivos de Ciências Veterinárias e Zoologia da UNIPAR, vol. 6, no. 1, pp. 27-30.

PEREIRA, M.E., SILVEIRA, A.F., GUEDES, A.G.P., KRUGEL, M.M. and CECHIN, S.T.Z., 2004. Hemocitometria em Saracura Sanã (Pardirallus nigricans). Revista Ars Veterinaria, vol. 20, no. 2, pp. 203-206.

RUPLEY, A.E., 1999. Manual de clínica aviária. São Paulo: Roca. 582 p. 
SANTOS, A.A., 2001. Aspectos morfo-citoquímicos das células sanguíneas e ultra-estruturais de trombócitos e granulócitos de Gavião carijó Buteo magnirostris (Gmelin, 1877) (Ave Falconiforme). São Paulo: Escola Paulista de Medicina, Universidade Federal de São Paulo, 97 p. Masters Dissertation.

SPARLING, D.W., DAY, D. and KLEIN, P., 1999. Acute toxicity and sublethal effects of white phosphorus in Mute Swans, Cygnus olor. Archives of Environmental Contamination and Toxicology, vol.
36, no. 3, pp. 316-322. http://dx.doi.org/10.1007/s002449900477. PMid: 10047600

STURKIE, P.D., 1976. Blood: physical characteristics, formed elements, hemoglobin, and coagulation. In: P.D. STURKIE, ed. Avian physiology. New York: Springer-Verlag, pp. 53-76.

VAN DER HEYDEN, N., 1994. Evaluation and interpretation of the avian hemogram. Seminars in Avian and Exotic Pet Medicine, vol. 3, no. 1, pp. 5-13. 